\title{
Corruption and Abuse of Power: A Reflection of Social Issues in Short Stories
}

\section{Endut Ahadiat}

Indonesian Literature, Faculty of Humanities, Bung Hatta University.

\section{Abstract}

The widespread of corrupt practices is a common phenomenon at present time. The possible causes encouraging the growth of corruption among public officials differ from place to place. It is probably right to believe that one reason might be the abuse of power. The chance of using one's power for personal gain had driven people to financial misconduct giving significant impact on society. Social issues as mentioned, become a particular interest for some writers. The critical awareness and the ability of a writer to express thoughts are two strong forces that may produce eloquent pieces of work. This is vividly seen in the works of three Minangkabau writers. Their exposure

Corresponding Author: Endut Ahadiat endutahadiat65@gmail.com

Received: 18 January 2019 Accepted: 24 March 2019 Published: 31 March 2019

Publishing services provided by Knowledge E

(c) Endut Ahadiat. This article is distributed under the terms of the Creative Commons

Attribution License, which permits unrestricted use and redistribution provided that the original author and source are credited.

Selection and Peer-review under the responsibility of the First ELEHIC Conference Committee.

\section{G OPEN ACCESS} of social issues, such as corruption and abuse of power, shows great concern on the matter. As a reflection of life, their works can be used as a precise means of conveying criticism towards social issues occurring globally. By exploring three chosen short stories, it is expected as a way to deeply understand and propagate social issues as well as to raise social consciousness, hence a small attempt to deter the phenomenon has been done.

\section{Keywords: social issues, corruption, abuse of power, social consciousness}

\section{Introduction}

Writers create literary works for the public to enjoy, understand, and to benefit from them [1]. Literature is created not only based on broad perspective on political, economic, social, and other issues, but also the reality of life in the society.

Literature is a story created by a writer, which comprise words. Thus, literature displays the world not only in a series of words, but they also showa world of possibilities. Words help build a story, but literature are not merely a series of words put together to create beauty, they also aren't just lines of words which meaning can be understood just by reading them only once. Literature paint pictures about life and they contain certain meaning of life that readers need to digest [2]. 
The meanings contained in literary works are the fruit of the writer's mind, thoughts, and views on life. A writer must possess rich creativity to blend reality and imagination in their works. Therefore, it is essential for a writer to have a broad perspective about politics, economy, religion, and others so that they can react indirectly towards those issues in their words. On top of the requirement to have the empirical facts, writers must also enrich their perspectives by consuming certain reading materials.

Literature is a social reality that undergoes the digestion process of their writer. However, literature is not a social life reality although they are always based on social reality. The social reality digested by the writer is a reality experienced and internalized by the writers in life. Such reality was then given a vision, revised based on imaginations, so that the world written in the works is not really the reality of life.

The social world is basically a world that exists outside and beyond the direct experience. In reality, direct experience has no society or social structure. There are only individuals and different objects that aren't connected to one another. With such understanding, the social world becomes really close to literary works [3].

No literary works can be fully comprehended without bringing the environment or culture or civilization that created them into the works [1]. The reason being is that writers are members of a certain society who live and interact physically with other people around them. That's why there are two-way relationships between writers and society, and between writers and literary works.

Writers who are part of a society are social creatures greatly influenced by their surroundings. Social, religious, and cultural backgrounds influence the writers' way of thinking and expressions.Writers want to communicate with the society through their literary works. It is no wonder why many literary works contain the aspects of life, such as the social interactions between members of the society. The social interactions lead to different wishes and expectations by different individuals.

Based on the arguments above, matters related to social criticism in literature (including short stories), need to be raised through a research so that the public can digest the meanings contained in the literary works (including poems). The research on social criticism in literature-short stories-is intended to let the public know that appreciations on social criticism in literature are needed. 


\section{Methodology}

The research on the social criticism is conducted through qualitative research adopting content analysis method and objective approach and mimesis using structural and sociological literary theory. As for the qualitative research, formal data are gathered from texts in the short stories comprising words, sentences, and opinions [4]. The content analysis technique is applied to systematically analyze data or contents/text messages of the story. Content analysis is normally used to describe the characteristic of a message. Content analysis is the longest and most effective text analysis method compared to other range of social empirical study methods [5].

According to Holsti [6], the analysis design focus is divided into three parts. First, to describe the text's characteristic. Secondly, to draw conclusion on what caused the message (encoding process). Third, to draw conclusion on the impact created by the communication (decoding process). By using content analysis, structural and sociological literary approach, a more focused analysis procedure with clear research measure and technique can be adopted. It can also determine clear validity criteria for data.

\section{Discussion}

The writers rooted their ideas in producing literature (short stories) on the shifting social values in the society. Some of the short stories that were studied contained corruption issues.

The short stories that talked about the crime (corruption) included those written by (1) Harris Effendi Thahar titled “Darmon" (2000); (2) Adek Alwi titled "Lampu Ibu” (2007), (3) Gus tf Sakai titled "Kaki yang Terhormat" (2009).

The research has shed a valuable insight on questions why corruption/ frauds occur. Most people are more familiar with the term corruption rather than fraud. In accounting, corruption is part of a fraud. Both actions are against the law and cause other people to suffer a loss. The study also shed a light on what is called fraud triangle. The writers of the Minangkabau descent described what corruption is in their short stories.

\section{Crime (Corruption)}




\subsection{Short story "Darmon"}

Events described in Harris Effendi Thahar's short story "Darmon" marked the birth of a short story in a newspaper by a story teller who replaced a journalist. There are moments when fragments of life flowed in strongly, scattered in news stories and risked to evaporate in time (although maybe some day they might become part of what is called "history").

If a short story is written because a person had something to say to others, and the things they want to say are sent to a newspaper with a large circulation, then it poses the question that seems difficult to answer: why did he write a short story? Why not write a paper, a letter to the editor, or a coverage?

As alternative, the writer came with a story. Every fragment offers the chance to be redeemed. A short story offers the opportunity to do just that. In the redemption, the fragments are no longer presented as a piece of information. They are no longer scattered. This is not because each segment blends with one and another, but because they have stopped being fragments that are different from a news story. The stories that later arrivedwere not intended to add or improve the previous ones. Each stands on its own. When the storyteller came and replaced the journalist, stories were born and they came to us with meaning because they took away the boundaries of "new" and "old".

Sometimes the researcher feels that the reduction of "reality" had made the short story become "deficit with characters". It is true that the appearance of the subject in Harris Effendi Thahar's Darmonis felt, but it felt more like a stereotype student activist rather than an individual personality - a layer of an organization, an example of "idealism" and living in poverty. The conversations here also do not suggest any character: the researcher can easily find one in an editorial or an interview in any newspaper. See data 6/D/DTK.

“... in your opinion, Mon, what do you think about the prospect of the Indonesian economy after the general election?"

“Well, here is my instinct, sir. I think if the war doesn't erupt because of discontent, another cheating, for instance, our economy will move very slowly. It will take three to five years. If you think about it, since it was brought down by Soeharto, it took us seven years to get back on our feet", he said calmly.(6/D/DTK) [7]. 
In the meantime, the revelation aboutcorruption is only featured in a dialog between the characters "l" and "Rini or my wife", during dinner in the dining room. See the following quotation of the text data 9/D/DTK.

I just chewed the food quietly, because once the wife starts to talk, it would revolve around staple food, how difficult it is to survive, living merely on a salary with no extra income. In the end, it will be about me not being able to please the boss that I am never given a project eventhough I have worked for over two decades as a civil servant (9/D/DTK) [7].

Next, in line with the quotation above, data 10/D/DTK contains the same conversation.

"Your father has always been like this from the beginning, really weird," said my wife Rini as I had earlier expected.

"What's so weird about me?"

"Talking nonsense with filthy looking students. So close. The other day, Sanip came over to discuss tactics to win a project, but you sent him away instead." "Him. Sanip is the master of nepotism in the office. What matters to him is that his pockets are full. He doesn't care where the money came from. $\mathrm{He}$ has been warned before. He was lucky our boss pitied him. Otherwise he would've been brought to justice," I explained.

"That's why you need to be smart so that we can have a better life."

I washed my hands quickly eventhough I still had food on my plate. I wanted to move to the porch immediately, to cool off in the hot month of February, after six months of dryness.

"Monetery yes monetery, people are living a comfortable life. But your father? Ask him to fix the car and he sold it instead. So now just enjoy it, ride those cramped buses every morning." (10/D/DTK) [7].

\subsection{Short story "Lampu Ibu"}

Adek Alwi's "Lampu Ibu", which is clearly a metaphore, is given street lamps and traffic signs. Surely there is nothing wrong with the illustration regardless the fact it came with a short story. However, this shows that you cannot automatically transform verbal language into visuals. It has to undergo differentvehicle transferring process based on 
the concept and view in accordance with the type of vehicle. A novel (literature-short stories) that is transformed into a movie can no longer be made as the basis to assess the new vehicle, and vice versa. We can watch a movie without reading the novel, or the other way around. However, a short story published in "Kompas" forces us to look at it as a visual at the same time: the pictures that came with it is definitely intended to serve as interpretation, line of script. Therefore, although in verbal language they aren't necessarily "close to real", in visual language it is made to look "real"- in accordance with what was being told, which functions the same as the pictures that are tagged along with a news story in newspapers [8].

Writer Adek Alwi brought up the corruption issue in the short story "Lampu Ibu", inspired by corruptions that involve political party members. The researcher thinksthe reason why writer Adek Alwi chose corruptions by politicians as the inspiration for his short story "Lampu lbu" is because it had become the talk of the general public. He probably pondered why corruption never resolved and why they weren't punished according to the Indonesian law. When his mother arrived at the Soekarno-Hatta Airport from her hometown, she asked him to take her to her son Palinggam's house (who allegedly committed corruption), a member of a political party. Read the following quotation. See quotation of text data 43/LI/CAPC short story "Lampu Ibu".

"Take me to see your big brother," she said when I picked her up from Soekarno-Hatta. "The following days I will stay at Nina's place." She always refer to her son's house by her daughter in law's name and call our children "my grand children". (43/LI/CAPC) [9].

On the way from the airport to big brother Palinggam's house, mother and I were engaged in a conversation. The conversation revolved around the upbringing of the children and blamed the big brother for being too busy with work that he forgot to take care of his family. Read the following text data 46/LI/CAPC.

Mother still looked unhappy when the story was told even after it was slightly altered to make it sound better. "Your siblings took the wrong paths!" she insisted. "Always busy. Never satisfied even with so much wealth. Letting the children grow on their own. Do you know that chicks are luckier than that!" (46/LI/CAPC) [9].

After reaching big brother Palinggam's house, they talked about events that are considered breaking the law (committing corruption). Big brother Palinggam explained to mother that he didn't commit corruption. He swore he did not do it. Read the following quotation of the text data $47 / \mathrm{LI} / \mathrm{CAPC}$. 
The three of them sat in the family room. They have stopped crying when I approached the room. Big brother Palinggam's voice sounded slow and sad as if asking for forgiveness. "But, I am still clean until this instance, mom. l'd be damned if I ever lied to you," he said.

"Well then, why did you avoid being questioned, son? Why did you pretend to be sick? Why didn't you just let everything out?"

"It's not that simple, mom."

"What's so difficult about it?"

There were silence. I emerged. My brother glanced at me. He sighed, and then looked at mother again. His expression was sad. Surrendered. "I have a superior, mom," he said as if asking for help. His voice continued to soften up to a point where it sounded like a whisper. "I have friends. I am also a cadre of a political party...."

Mother was quiet. Big sister Andam and I were also quiet. Then slowly and softly I heard a voice.

"I don't understand about those things, Palinggam," said mother. "But, for me, son, you have to tell the truth no matter how hard it is. I would rather see you get fired from your work, your party than to have you betray the truth, your conscience, also God. Your father helped defend this country from colonialists." (47/LI/CAPC) [9].

\subsection{Short story "Kaki yang Terhormat"}

Writer Gus tf Sakai described corruption in his short story "Kaki yang Terhormat" in a subtle way. The story was about how everyone in the whole town was admiring their fellow town members who successfully became rich after going away for a little while. It was described in the story that not only his family was proud of him, but also the whole town, people in the whole district and region were also proud of him.lt was a much talked pride because Mak Etek was richer than the richest people in town who had only one or two cars. Mak Etek even owned a helicopter and ride on it when he goes out.

However, the pride quickly went up in smoke after news spread that Mak Etek was involved in corruption with some big shots. The people in the whole town became aware of what Mak Etek has done because it was reported all over newspapers and television. Read the following quotation of the text data $61 / \mathrm{KT} / \mathrm{PSH}$,AIR. 
The whole town was shocked. Even the whole district. People in the whole region wouldn't stop talking about it.

For days, weeks, Mak Etek was on the news. There were no more fairy tales because now people can see who the real Harun is. His face constantly appeared on the front page of newspapers and on television. (61/KT/PSH,AIR) [10].

\section{Conclusion}

Social criticism in litereature is a form of communication in the society aimed at or that serves to control the social system or the socialization process.

Literature as a process of communication offers a wide comprehension. According to Duncan, art works contain ideal communication forms because art works offer experience on the quality of interrelationship [11]. So it is clear that art works, especially literature are a form of communication for writers. This is because texts have the potential to carry information about the social life of the society, arts, technology, and science. Writers use language, in this case texts as the weapon to build ideology.

Literature is not merely a product but it is a human product that forms a certain building that came from a reality of a certain context, they are created and consumed by the society to respond to to certain experiences in their world. Based on the sociological literatureperspective, literary works should strongly reflect the reality of life. Literature plays a role in building the society, while on the other hand the society plays a strong role in producing literary works.

Literature serves as a language to communicate with other fields that grow in line with the shift in the society. The symbols used in literature are symbols that are used in certain area at a certain time. The concept of symbols here is closely related to the growing socio cultural context.

In a literary work, the relationship between the writer and readers should be understood as a meaningful relationship, open and productive relationship patterns that carry social implications and not as a single causality. The writer created shapes that allow two-way communications. The writer continuously explored the significance of functions of the social interaction symbols in the activities of the human lives. On the other hand, in line with the factual design, writers connected them with imaginative and creative quality which automatically supported the literary life as a whole. 
Literature, as a form of cultural creativity, a super representation of ideological structure, is viewed as a social phenomenon that consists of complicated information system [11]. On one hand, literature is a response to social interaction, a social phenomenon as the result of interrelationship in the society. On the other hand, literature offer a world of fabrication to the readers in the sense that this is where ideas about literary communication lie. The relationship between literature and the society is not meant to explain individual relationships, but group relationships where individuals are actively involved.

Literature functions as a social criticism. Social criticism in literature is a form of communication in the society aimed at or serves to control a social system or the socialization process. It is concluded that social criticism is an activity related to assessment, comparison, and revelation about the social condition of a society regarding the values they adopt or hold as guidelines. Anybody can launch criticism, including writers and social criticism is an important variable in maintaining the existing social system.

Literature is created by a writer who is free to add colors into their works and therefore the contents are a piece of work tied to the writer. So, a writer is free to decide what to put in his works. The freedom is pretty much to do with the writer's goal. By starting with the goal, the literary work becomes the communication tool for the writer. Basically, literature is crystallization of values of a society. Although a good literary work generally don't immediately paint the picture or fight for certain values, the aspiration of the community will automatically be reflected in the works. That's why, descriptions of socio-culture and lives of the society have always been an inseparable part of literature and the decription is a form of communication between writers and readers.

Literature is a fruit of dialogs and contemplation and writer's reaction towards the surrounding and life (Nurgiyantoro, 1998: 4). Literature contains appreciation and intense contemplation, full awareness, and it's the writer's responsibility towards the essence of life. To understand literature in a complex way, you have to look at the context.

\section{References}

[1] Damono, S. D. (2000). Pedoman Penelitian Sosiologi Sastra. Jakarta: Pusat Bahasa Depdiknas.

[2] Wardani, N. E. (2009). Makna Totalitas dalam Karya Sastra. Surakarta: LPP UNS dan UNS Press.

[3] Faruk. (2012). Pengantar Sosiologi Sastra: dari Strukturalisme Genetik sampai Postmodernisme. Yogyakarta: Pustaka Pelajar. 
[4] Ratna, N. K. (2012). Teori, Metode dan Teknik Penelitian Sastra: dari Strukturalisme hingga Postrukturalisme. Yogyakarta: Pustaka Pelajar.

[5] Ibrahim, A. S. (2009). Metode Analisis Teks \& Wacana. Yogyakarta: Pustaka Pelajar.

[6] Holsti, O. R. (2009). "Analisis Isi” dalam Stefan Titscher, dkk. Metode Analisis Teks dan Wacana. Yogyakarta: Pustaka Pelajar.

[7] Thahar, H. E. (2000). "Darmon” dalam Ninuk Mardiana Pambudy dkk. (Ed.). 2000. Dua Tengkorak Kepala: Cerpen Pilihan Kompas 2000. Jakarta: Penerbit Kompas.

[8] Mohammad, G.(2000). "Kenapa Menulis Cerita Pendek?" dalam Dua Tengkorak Kepala Cerpen Pilihan Kompas 2000. Jakarta: Penerbit Harian Kompas.

[9] Alwi, A. (2007). "Lampu Ibu" dalam Ninuk Mardiana Pambudy dkk. (Penyunting). 2007. Cinta di Atas Perahu Cadik: Cerpen Pilihan Kompas 2007. Jakarta: Penerbit Kompas.

[10] Sakai, G. tf. (2009). “Kaki Yang Terhormat”dalam Efix Mulyadi (Penyunting). 2009. Pada Suatu Hari, Ada Ibu dan Radian: Cerpen Pilihan Kompas 2009. Jakarta: Penerbit Kompas.

[11] Ratna, N. K. (2003). Paradigma Sosiologi Sastra. Yogyakarta: Pustaka Pelajar. 